\title{
Electronic Banking and Profitability in the Nigerian Banking Industry
}

\author{
Uchenna Aduaka ${ }^{1}$, Olawumi D. Awolusi² \\ ${ }^{1}$ University of Roehampton, London, UK \\ ${ }^{2}$ Department of Accounting and Finance, College of Economics and Management, Kampala International \\ University, Kampala, Uganda \\ uchenna.aduaka@roehampton-online.ac.uk, awolusi.olawumi@kiu.ac.ug
}

\begin{abstract}
The primary objective of this study was to assess the impact of electronic banking on profitability in the Nigeria banking industry. An inferential survey research design was adopted. Primary data were collected through questionnaires from both staff and customers of the surveyed bank. It was complemented with secondary data sourced from the company's audited financial statements for the period 2010 to 2017. Data collected were analyzed using both descriptive and inferential statistics while testing of the hypotheses was done using multiple regression analysis. The study revealed that cards play a significant role more than other channels and immediately followed by ATM. Also, it was observed that E-Banking channels contributed to Bank's profitability, that E-banking services (EBS) had an influence on the retention and loyalty of bank's customers and that the quality of service, security, reliability and efficiency have a definite impact on the usage of the services of e-banking. It was recommended that the Nigerian banking industry should invest more in card products, followed by ATM amongst other electronic channels; as they generate more revenues for the bank. The study also recommended further development of other channels (Mobile, Corporate Payments, POS and internet banking) to further enhance their contribution to the bank's profitability. Nigerian banks should also create a business strategy that is customer-centric by being continuously innovative in identifying the needs of their customers and improving on their products offering while developing new ones, to retain and keep the loyalty of their existing customers while attracting new ones.
\end{abstract}

\section{Keywords: Electronic banking; profitability; banking industry; regression analysis; Nigeria.}

\section{Introduction}

The prevalence of Internet services along with the fascination of e-business which is on the increase globally has forced cash transactions movement to give way to pay via electronic platforms. Since accepting this steadily increasing digital way of life, substantial changes have occurred in customers' expectations from financial services providers (Matira \& Awolusi, 2020; Salehi \& Alipour, 2010). It is estimated that with its value of about US\$540billion in the year 2015, e-commerce value in China will exceed that found in the UK, Germany, France, Japan, and the U.S combined by the year 2020 (Rauf, 2014). According to Kaur (2013), more people shift from doing transactions on paper to electronic means of doing transactions due to the lower cost involved in doing transactions electronically. Furthermore, technology is currently regarded as the key contributing factor to the success of organizations in general and banks in particular. Hence, banks, either foreign or local are consistently investing more towards giving their customers access to new technologies via e-banking because of the response and actions exhibited by the customers towards technology acceptance. This is consistent with the social construction of technology theory where the actions exhibited and displayed by humans are what put technology in shape (Blazi \& Awolusi, 2020).

Similarly, a remarkable upsurge in the number of persons that have adopted the internet and mobile banking which has been attributed to acceptance and user-friendliness, along with the number of mobile phone users because what determines the use of a system is the behavioral intent to make use of the system (Awolusi, 2012). This is also consistent with the Technology acceptance model about the internet and mobile payments. There is also an increasing partnership between financial institutions with non-financial service providers in which consumers via the usage of e-banking channels (Mobile banking etc.) can pay various utility bills on the banks' application platforms. Incorporated in the year 1989 as a commercial bank with private ownership and subsequently listed on the floor of the Nigerian Stock Exchange in the year 1998, Access bank Plc (Access) renders services to their clients through its various business divisions that comprise business banking, corporate and investment banking, commercial banking and personal banking. There has indeed been an evolution in Access from obscurity as a local bank in Nigeria to a global standard financial institution in Africa that has relished what could arguably be regarded as the most successful growth curve in banking. 
In Africa in the past ten years, standing amidst the top 20 banks in Africa by total assets and capital in the year 2011. There is indeed a considerably superior performance by organizations whose strategic styles are matched with their environment than those that theirs are not matched (Reeves et al., 2012). Similarly, in the Nigerian banking industry today, they are amongst the five largest banks in terms of branch network, deposit, assets and loans; an accomplishment which has been realized via providing committed, innovative and sustainable long-term solutions to their clients' banking needs (Accessbank.com). According to Eccles and Serafeim (2013:4) as the environmental, social, and governance (ESG) performance of organizations improves, their financial performance declines once there is no significant as well as considerable innovation. Driven by their vision and focusing on their mission, they have had only two CEO's since 2002 in the persons of Aigboje Aig-Imoukhuede who was appointed by the board in March 2002 as the Managing Director/Chief Executive Officer before he retired in 2012 and the Deputy Managing Director, Herbert Wigwe took over as the Managing Director/CEO till date. At present, their banking operations which are constantly looking at expanding its services in Africa cut across over 365 networks of branches around the state capitals and commercial city centres in Nigeria as well some African countries which include; Democratic Republic of Congo, Zambia, Rwanda, Sierra Leone, Ghana, Gambia and in the United Kingdom. As quipped by Pitt and Koufopoulos (2012), the business activities of banking are influenced substantially by the changes in economic factors that are its issue-drivers.

Their strategic focus is to profitably provide consistent economic growth in a sustainable manner that takes cognizance of the social as well as the environmental impact of their operations (Awolusi \& Akinruwa, 2014). According to Collins (2001:144), technology facilitates quick implementation of strategy, enables change and also enables a firm to be ahead of its competitors. Access bank has indeed been able to create economic returns which are sustainable through the use of technology and execution of the bank's digital banking plan. Hence, its selection as a case study in addition to their consistent performance part of which electronic banking plays a significant role. The Basel Committee on banking supervision defined $e$-banking as "the provision of retail and small value banking products and services through electronic channels". "Such products and services can include deposit-taking, lending, account management, the provision of financial advice, electronic bill payment, and the provision of other electronic payment products and services such as electronic money (Basel Committee on banking supervision, 1998 \& 2003). The versatility of e-banking as a multichannel means of delivery of banking services makes it complex to be explicitly defined in literature as it is usually interpreted differently depending on one's assessing viewpoint. For example, Simpson (2002) termed it as an electronic means through which customers carry out their banking transactions without accessing the physical structure of bricks and mortar while Kricks (2009) defined it as an automated delivery, directly to the customers, innovative as well conventional banking products and services via electronic and interactive channels.

There has been a wide acceptance of electronic banking in Nigerian banks and technology has become more popular as service offering to customers have become more convenient, thereby, leading to an increase in competitiveness and profitability. There is a swift variation in the method of conducting business globally and in Nigeria, particularly which is borne from advancement in e-banking. LeBeouf (1987) has said that it is becoming progressively difficult to satisfy customer expectations. Reason being that they desire to get their money's worth the way they see it. Thus, the commencement of electronic banking in the Nigeria banking industry has fully altered the mode of operation of banks with resourceful and evident redefinition (Onikoyi, Babafemi \& Awolusi, 2013; Sumra et al., 2011). Consequently, limitations of banking services in addition to physical restrictions set by locations are eliminated by electronic banking. These developments technologically have made way to groundbreaking and new ways of delivering banking products and services e.g. electronic bills payment, account management, deposit-taking, lending, Electronic Funds Transfer at Point of Sale, Mobile banking and its estimated improvement on the profitability of banks. E-banking gives customers that unique ease to carry on banking transactions at any suitable time of the day such that customers can transfer funds between accounts even across geographical borders, access funds, make purchases and pay various bills round the clock. For the banks, it boosts the brand image, increases profitability, reduces operating costs, facilitates wider reach, opens new market opportunities and improves customers' satisfaction. Even though the evaluation of most studies revealed that the profitability of banks has tremendously improved since the commencement of electronic banking, there is also diverse evidence regarding the effect of electronic banking on the result of banks. 
Hence, bankers, regulators and scholars must comprehend exactly how e-banking affects banks' performance. This research is distinct from any other because it seeks to highlight the contribution in definite terms (impact) of electronic banking channels to profitability in Nigeria banking industry with Access Bank Plc as the bank of interest. Access Bank was chosen for this research because it is one of the eight systemically important banks in Nigeria and arguably one of the best as regards e-banking amongst the top five in the Nigerian banking industry in addition to their consistent growth in profitability. Despite the huge interests in the research of electronic banking which indeed has brought numerous advantages as well as benefits to banks and their customers, in terms of inadequacies regarding the adoption of electronic banking, several studies have also been examined. While banks may come across new issues which could be challenging, the major challenges to e-banking include cost, intense competition and management of risk (Kolodinsky \& Hogarth, 2004; Yang et al., 2009). Indeed, competition is strong in the Nigerian banking industry landscape, though overall, it could be said to be moderate as every player is looking for ways to out-do the other forprofit maximization. Access Bank as one of the major players in the industry has their fair share of the ebanking challenges stated above just like the other players in the industry.

This is because the industry is a congested marketplace that comprises banks, advisory firms, investment banks, mortgage banks, microfinance banks, insurance companies, credit card issuers, credit unions, amongst others, all of which play actively in the industry. These players require a dependable, secure and safe ICT setup in place and the providers of these products and services which can evaluate the ICT requirements of banks like Access and proffer solutions which empowers them as suppliers tend to be large. In the same vein, the network operators for ATM transactions and card processing who are few and large also have enormous power over the players in the industry with who they enter into partnerships. Similarly, it is costly to keep up with regulation in the banking industry, which poses a very high entry barrier (Awolusi \& Onigbinde, 2013). Furthermore, the network of transactions done via card payment and Automated Teller Machine network are provided by separate financial services bodies like MasterCard, Visa and American Express. These distinctive corporations have partnerships with bank issuers of these payment cards to operate via their paymentprocessing network and these network operators have substantial powers as suppliers because they are the linking service to processing of payments worldwide for the banks' clients and all these services are costintensive.

Cost: Apart from the cost involved in training the staff responsible for operating e-banking channels, there is a need for banks to spend reasonable time as well as money on the services provided by e-banking to attract customers. Similarly, staff in e-banking unit is expected to have strong technical background and banks usually have challenges getting such talented people, training them and retaining them. This is aside from the cost involved in getting the infrastructure, establishing the system, maintaining and updating the software (Angelakopoulos \& Mihiotis, 2011).

Intense Competition: Since the emergence of internet banking where various types of transactions can be done across the web, competition has become very intense among banks. This is because; every customer can access the website of all the banks just by the click of a button and in the luxury of their homes. Hence, there is a basis for comparison of the same products and services to make the best choice.

Management of Risk: Customers must provide some personal information before they can have access to ebanking services. Hence, banks are faced with a high risk of keeping customers' information private while also managing the security risk because of the activities of the hackers. In the same vein, banks are also confronted with the task of managing reputational risk associated with unauthorized access to its customers' account with its attendant legal issues. Despite these challenges, this study primarily intends to unravel the contribution of e-banking channels to Access Bank's profitability as a case study. In summary, the Nigerian banking industry has experienced a tremendous transformation with efficient and visible redefinition since the advent of electronic banking. Despite several benefits and merits of e-banking concerning the customers and the banks, the major challenges to e-banking include cost, intense competition and management of risk. This is due to the congestion in the marketplace with every player trying to out-do the other for market share while managing the risk of privacy, security and reputation inherent in e-banking and also keeping low the cost of infrastructure, software, training and operating the channels. 
Consequently, the primary objective of the study was to assess the impact of e-banking on Access Bank's, profitability. However, the specific objectives are:

- To determine the influence of e-banking channels on the profitability of Access Bank.

- To determine the influence of e-banking on customer's retention and loyalty.

- To evaluate the quality of service, security, reliability and efficiency of Access Bank's electronic banking services to its customers.

To discover the specifics regarding my study topic, a thorough breakdown was done on the questions below:

- What is the contribution of electronic banking channels to Access Bank's profitability?

- Does e-banking have any influence on the retention and loyalty of bank's customers?

- Are there improvements in the quality of service, security, reliability and efficiency due to the usage of electronic banking services? These three questions shortened the scope of the research, but the study as a framework, and aid in managing the research project (Easterby-Smith et al., 2012). The relevance of this research was to highlight the actual contribution of electronic banking channels such as POS, internet, Mobile Applications, Electronic Cards and ATM etc. to profitability in Nigeria banking industry with Access Bank Plc as a case study using statistical models.

There seems to be no study focusing on the actual contribution of e-banking channels to the profitability of banks and as such, this novelty of the present study. The issues and opportunities were meticulously evaluated and its effect on operational efficiency was also investigated. About practical relevance, the study examined profit before tax (PBT) and profit after tax (PAT) for a period of 8 years specifically 2010 - 2017. It is pertinent to note that the profit part of the income statement encompasses "Net interest income after loan impairment charges" and "Net fee and commission income" before "Total expenses deductions". The income from e-banking channels (POS channels, ATM channels, Internet banking, Mobile Banking and Cards) which was included in the "Net fee and commission income" was extracted and evaluated to ascertain its contribution to the Net fee and commission income, profit after tax as well as the contribution of each of these channels separately to profitability. The result of this study will be of great relevance to stakeholders in the Nigerian banking industry because there would be a clearer understanding of the actual contribution of electronic banking channels to the profitability of banks in Nigeria. Furthermore, it would assist them in making choices that would have a positive impact on the quality of service from these channels and to also invent ways of overcoming the challenges encountered by customers while using these channels. Likewise, it will also be very helpful to future academics as it would serve as literature for further study on e-banking.

\section{Review of Related Literature}

Conceptual Review: The drive and craving of any Business venture are to make money whilst creating commensurate value for customers (Blazi \& Awolusi, 2020). In the same way, the foremost objective of banks is to give excellent service more expediently to their customers and be rewarded with good profit and increased market share, hence, the wide acceptance and clamor for e-banking in the Nigeria Banking industry. According to Rad et al. (2017), electronic banking can be defined as a unique kind of banking that exploits electronic domain like the internet for the delivery of banking services such as funds transfer, cash withdrawal and deposit, balance inquiry, the printing of statement, verification of signature, etc to its customers. It is apparent that since the emergence of this technological advancement and innovation which has had a positive impact on business transactions by making them seamless and almost effortless, its effect has not only been felt in banking and other financial services but also the economy and its potential for sustainable growth is evident. As opined by Coombs (1987), developments in information handling as well as processing, telecommunications, and associated technologies- referred jointly as "information technology" (IT) - are often accompanied with enhancing extraordinary growth in several economies.

Theoretical Review: The rate of development of payment systems is largely dependent on a tussle between usual impediments to the acceptance of new products or service and speedy technological transformation (Olatunji \& Awolusi, 2019; Lai, 2016). Consumers' acknowledgements of new technologies, as well as their intent to make use of these technologies, have been proposed to be explained by some theories. However, for this study that sought to determine the impact of electronic banking on profitability in Nigeria banking 
industry [a case study of Access Bank Plc], the basis would be on the social construction of technology theory (SCOT), the Theory of Reasonable Action (TRA) and Technology Acceptance Model (TAM).

Social Construction of Technology Theory: This theory otherwise known as SCOT in the Science and Technology field holds that there should be a critical look at the social world for those that look for the comprehension of the bases of a technology recognition or rejection (Matira \& Awolusi, 2020). Hence, technical supremacy or superiority is not the only basis for a technology acceptance but also the social factors. Under this theory, the foremost proponents contend that technology is not the determinant of the actions of humans, but rather, that the actions exhibited and displayed by humans are actually what put technology in shape. They also contend that without comprehending how technology is entrenched in its social perspective, the usage of technology can also not be understood. In general, SCOT is a theory about how a diversity of social factors and forces adjust technological advancement, technological transformation, and the connotations related to technology. As a methodology is validated the required steps in the event of analyzing what is responsible for the success or failure of technology. This theory is used in this study to explain in what manner e-banking is adopted.

The Theory of Reasonable Action (TRA): It postulates that the behavior of humans is expected by the intent of an individual to involve in a particular behavior. The intent, on the other hand, is subject to two factors, which are the attitude of the individual as a consequence of the behavior and the views of the individual's social environment, referred to as the subjective norm (Fishbein \& Ajzen, 1975). TRA hypothesizes that when there is a positive assessment by a person or an individual to execute a behavior, the intent to perform that behavior becomes higher (Ajzen, 1991). There has been a successful application of TRA in internet banking services environment to forecast behavioral performance and intent. As an example, it has been used in Taiwan to evaluate the effect of the attitude of customers and subjective norm on internet banking adoption (Shih \& Fang, 2004). The outcome showed that attitude has a substantial effect on adoption intent, whereas subjective norm did not. The intent of the user to make use of, agree or adopt one or more of the IT areas is what behavioral intent determines according to TRA. It is used to explain the adoption of electronic banking by banks in this study.

Technology Acceptance Model (TAM): The development was by Davis, Bagozzi, and Warshaw (1989) to show technologies as well as information systems recognition and acceptance by the users. The theory stated that users' decision is affected by several factors regarding when and how new technology can be used when presented (Davis, 1989). Its application has been to various innovative technologies like internet banking, mobile commerce and the implementation of mobile internet since it was developed (Hong et al., 2006). It has also found its application in various educational perspectives like online education (Ngai et al., 2007) as well as mobile learning (Liu et al., 2010). TAM is useful in the description of electronic banking adoption by banks, as well as to forecast, comprehend and to offer an explanation as to the reason to accept or reject information systems by people. This theory utilized in this study for the explanation of e-banking adoption and by what means it influenced Access Bank's profit.

Empirical Review: Mawutor (2014) in his research work on "Impact of E-Banking on the Profitability of Banks in Ghana" suggested that profitability of banks in Ghana has greatly improved since the dawn of electronic banking joined with the increase in several customers resulting from effective and efficient services. The researchers studied the effect of e-banking services in general through the internet and ATM and the impact that they have on the profitability of, particularly banks. The method of research was quantitative; also the form of study was descriptive as three profitability variables were evaluated from the financial statements which were Margin, Return on Asset (ROA) and Return on Equity (ROE). There was also self-administration of structured questionnaires to certain branches of Agricultural Development Bank that was used as a case study.

Some of the bank's customers were also interviewed to obtain information about e-banking. In the journal titled 'Electronic Banking and Bank Performance in Nigeria' Abaenewe et al. (2013) alluded that the use of electronic banking was progressing in Nigeria in comparison with the other African countries. The difference in performance pre and post the adoption of electronic banking for performance indicators such as ROE and ROA with an acceptable level of significance pegged at 5\% using the standardized statistical method was 
analyzed by the researchers and the outcome demonstrated that e-banking has had a positive impact on returns on equity (ROE) of Nigeria banks but yet to have a notable improvement on the returns on assets (ROA) as far as the tested hypothesis was concerned.

There were extractions of secondary data of appropriate years from the Nigerian Stock Exchange Fact Books and published annual reports of four prudently chosen Nigerian banks through judgmental sampling. In "The Impact of Electronic Banking on Customers' Satisfaction in Ethiopian Banking Industry (The Case of Customers of Dashen and Wogagen Banks in Gondar City)" a journal by Worku et al. (2016), it revealed that most people who use e-banking services were young people, salary earners, students and educated people. It was also discovered that most businessmen and women do not use e-banking services actively, thus, highlighting that there was a connection between electronic banking and demographic characteristics also, that there was an enhancement of customer satisfaction due to e-banking. They also observed a lessening in the footfall to the banking hall by customers who desire banking services and also a drop in waiting time. The indices for customer satisfaction improved greatly following e-banking sign-on. Customer satisfaction can be said to be the overall number of customers who reported that their experience with a firm's products or services exceeded set satisfaction targets or objective (Mukonga \& Awolusi, 2019; Farris et al., 2010). Additionally, in a research project titled, "The Effect of Electronic Banking on Profitability of Commercial Banks in Kenya" Njogu (2014) emphasized that e-banking has aided banks to considerably lessen their cost of banking by utilizing technology to provide flexible products to its customers.

A quantitative methodology was used to obtain data from the Central Bank of Kenya and some Commercial banks. Regression analysis was done which covered a period of 5 years starting 2009 to 2013. The study clinched that there was a strong positive connection between financial performance and electronic banking and the bank size also had a positive impact on the financial performance of commercial banks in Kenya. Electronic banking using the internet as a tool has advanced beyond the limitations set by traditional brick and mortar system of banking to describe market, product and customer majorly in the global financial industry. Now, most researchers are interested in the tremendous positive effect of e-banking on the overall performance of banks. Three (3) years after the introduction of internet banking, those that implemented it experienced more profitability than those who didn't use ROE, ROA, etc as variables (Hernando \& Nieto, 2006). Owing to the trending debate on its effect on performance, some researchers resolved that operational costs for banks are reduced (Cheng et al., 2006); it was also established by Jayawardhena and Foley (2000) that with the introduction of new products and services, existing clients are retained while new ones are enticed. The value of banks can also be boosted because the benefits of e-banking can be emphasized through advertisements and promotional activities (Devi et al., 2012). From the evaluation of certain literature, most of the studies have focused on measuring the effect of internet banking on customer commitment and satisfaction (Singh \& Kour, 2011; Ma, 2012).

Some sought to find if electronic banking improves bank performance (Yang et al., 2018), others focused on the relationship between demographic characteristics and electronic banking (Worku et al., 2016). Similarly, some studies focused on factors that affect the adoption of e-banking (Ashtiani \& Iranmanesh, 2012) while some focused-on service quality (Lee \& Lin, 2005), impact of trust and its experiences (Wang et al., 2009) as well its assistance in reducing the cost of banking operations (Njogu, 2014). Whereas the evaluation of most literature eluded that the profitability of banks has greatly improved since the emergence of electronic banking. This research is unlike the others in that it searched for the answer to the question of contribution in definite terms of electronic banking channels to profitability in Nigerian banking industry using Access Bank Plc as a case study through statistical models. As far as I know, no study addressed the influence of e-banking channels on the profitability of banks this way as a topic on its own. Consequently, in addition to answering the research questions stated above, the hypotheses below were tested by the study:

$\mathbf{H}_{1}$ : There is no contribution of e-banking channels to Access Bank's profitability.

$\mathbf{H}_{2}$ : E-banking does not have any influence on the retention and loyalty of the bank's customers.

$\mathbf{H}_{3}$ : There are no improvements in the quality of service, security, reliability and efficiency due to the usage of e-banking services. 


\section{Methodology}

Research Design: There are four (4) basic parts of a Research paradigm; they are ontology, epistemology, methodology, and methods (Awolusi \& Onigbinde, 2013; Awolusi \& Akinruwa, 2014). Crotty (1998:3), opined that ontology has to do with 'the nature of existence' and it is regarded as the exit path of all research (Grix, 2004). Epistemology, on the other hand, has to do with 'the nature of knowledge'. It deals with the form of relationship which is in existence between the knower and the known. It can also be regarded as 'A general set of assumption about ways of inquiring into the nature of the world' (Easterby-Smith et al., 2012). As stated by Grix (2004:58), ontology and epistemology can be regarded as the bases upon which research is made. This is simply because the methods and methodology selected for research are informed by the assumptions of the researcher's ontology and epistemology. Therefore, there is a vital and fundamental relationship between the two. However, three research paradigms approach exist, and they include Positivist, Interpretive, and Critical. The approach to my research paradigm was a positivist approach because they believe in the likelihood of cause-effect relationship establishment.

As a result, there is the possibility of analyzing social world using scientific methods because they always seek to estimate, predict as well as institute scientific laws. Hence, they believe a neutral researcher's role is simply to give an objective clarification of important matters and forecast laws. Thus, my research paradigm is madeup of a 'Positivist Epistemology' and a 'Realist, foundationalism Ontology'. Epistemologically, a positivist researcher's view is dualist and objectivist. Accordingly, being objectivist as a researcher is a vital feature of any expert analysis. This is because both the knower and the item to be known are mutually exclusive and none of them exercises influence over the other. Positivists' researchers are captivated by facts and there are preventive measures to mitigate any danger to validity. Positivist methodology tries to explain "what" of relationships and through experiments, hypotheses are tested, and questions are substantiated (Awolusi, 2012; Onikoyi, Babafemi \& Awolusi, 2013). Simple random sampling data collection technique is what Positivist researchers use for numerical or quantitative data collection which would be statistically analyzed upon placing in a tabular form. The present study, therefore, seeks to unravel "what" using quantitative research methodology. Four (4) main types of data are collected using quantitative research.

The first data is about individual performance, the other measures the attitude of the individual, the next is the observation of the behavior of individuals and the last is factual. Irrespective of the method of research a researcher wishes to adopt, whether quantitative or qualitative; explanatory or exploratory, the hypothesis is at the middle of every research Endeavour. It is the interim response to the question the research tries to find out which provides a direction to the whole research. Similar to previous studies, inferential statistics were used in testing the hypotheses and as stated earlier in Fig. 1 above, the profit data for the period $2010-2017$ of the case study organization was used for the analysis. Also, Net interest margin (NIM) being a profit variable was used in testing the hypothesis. Upon gathering the profit figures in terms of contribution of various e-banking channels as stated in Table 1 below, the calculation was done to determine the mean, variance and standard deviation for the period 2010 to 2017. Mean incidentally is the most commonly used in measuring central tendency to find the point of balance in a series of data while standard deviation is used to show the distribution of all the data values (Berenson, 2006).

Dependent and Independent Variables: The profitability ratio (Net Interest Margin) of the bank regarding this study will be the Dependent variable, while the Independent variables concerning this study were POS, ATM, CARDS, Internet Banking, Mobile Banking and Corporate Payments. Profitability which is usually measured by Price-Earnings Ratio needs to be influenced by the Independent Variables to be qualified as the Dependent variable. For the testing of the influence of e-banking on Access bank's profitability, a logistic regression model stated below was used:

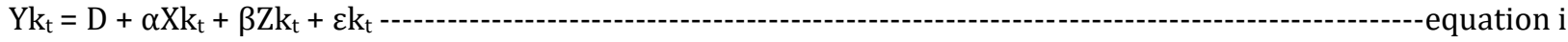
Where $\mathrm{k}$ denotes Access bank; $\mathrm{t}$ denotes the year; Ykt is the dependent variable and denotes the profit (Net Interest Margin) of $\mathrm{k}$ (Access bank).

In a specific year t; D is the point of interception; $\mathrm{X}$ signifies the independent variables which include; Cards, Mobile, Internet Banking, POS, ATM and Corporate Payments while Z denotes the other profitability 
determinants of Access bank; $\alpha$ and $\beta$ are coefficients and ekt represents the error term. In this study, multiple linear regression model was used to evaluate the influence of electronic banking on profitability of Access bank and it is stated as follows:

$\mathrm{Pkt}=\mathrm{D}+\beta 1 \mathrm{POS} \mathrm{kt}+\beta 2 \mathrm{ATM} \mathrm{kt}+\beta 3 \mathrm{CARDS} \mathrm{kt}+\beta 4 \mathrm{IB} \mathrm{kt}+\beta 5 \mathrm{MB} \mathrm{kt}+\beta 6 \mathrm{CP} \mathrm{kt}+\varepsilon \mathrm{kt}-------------$ equation ii Where;

Pkt $=$ Profitability (Net Interest Margin)

POS = Point of sale which was determined by the ratio of fees and commission generated from point of sale terminals over the bank's total fees and commission for the year.

ATM = Automatic Teller Machine which was determined by the ratio of fees and commission generated from ATM over the bank's total fees and commission for the year.

CARDS= Income from both debit as well as credit cards which was determined by the ratio of fees and commission generated from the cards over the bank's total fees and commission for the year.

IB = Internet banking which was determined by the ratio of fees and commission generated from internet banking over the bank's total fees and commission for the year.

MB = Mobile banking which was determined by the ratio of fees and commission generated from mobile banking over the bank's total fees and commission for the year.

$\mathbf{C P}=$ Corporate payments which were determined by the ratio of fees and commission generated from Corporate payments over the bank's total fees and commission for the year.

$\boldsymbol{\varepsilon}=$ Error term

The profit variable (dependent) stated above was tested upon getting the required data using P-Value. Where the P-Value = "The level of significance within a statistical hypothesis test that represents the chance, probability or the likelihood that a given event would occur'. Generally, it is utilized as an alternative that afforded the least level of significance for the null hypothesis $\left(\mathbf{H}_{\mathbf{0}}\right)$ to be rejected, implying the lesser the $\mathrm{p}$ value, the more the evidence is in favour of the alternative hypothesis $\left(\mathbf{H}_{\mathbf{1}} \mathbf{)}\right.$. Conventionally, the choice of level of significance $5 \%$ is generally taken as $5 \%$ to reject the null hypothesis $\left(\mathbf{H}_{\mathbf{0}}\right)$, even though it is arbitrary. Nevertheless, the level of significance of $5 \%$ at $95 \%$ confidence interval was also used for the null hypothesis to be rejected as well as to determine the significance of the regression model about this study.

Research Instrument, Data Collection and Analysis Plan: Data collected from the company's record and complemented with secondary data from the audited annual reports in excel and questionnaires were the research instruments that were used for this research. The objectives of my study areas enumerated above. However, the factors that influenced my questionnaire design were: my target respondents; who were youths and working-class individuals that were technology savvy, as well as, the method through which I reached them (which was self-administration). The response anticipated from the respondents was categorized as; Strongly Agree, Agree, Not sure, disagree and strongly disagree for each of the questions in the questionnaire. Space was also provided for respondents to tick their age range, gender, marital status, current educational status and occupation which were also included as part of the analysis. Appropriate data which were obtained from the company's records, internet and financial statements of the Bank.

For the period 2010 -2017 and questionnaires were used to explore respondent's knowledge, perceptions and assessments. To support the hypothesis and conclude, the quantitative approach to data analysis was employed as it seeks to interpret and advance knowledge through numerical data processing. Regression analysis was used with the help of SPSS in the study. Furthermore, regression analysis was further employed to discover the significance of the relationship between the variables as stated above. The settings of my study were selected branches of the case study bank, Access Bank. The banking halls of the bank branches where day to day transactions take place as well as the marketing staff floors were the settings of the research. The target population was the staff of the case study bank, youths and working-class customers of the bank(s) who were technology savvy with an age range of between 20 to 55. The vulnerable population was not involved in the research.

Sampling Method and Procedures: Simple random sampling technique was the data collection method used. Here, questionnaires were self-administered to 25 members of staff and customers of each of six (6) selected branches of Access Bank because they were the key initiators, managers and users of these services. Secondary data was also collected from the internet, the bank's financial statements and symposia papers on 
topics related to the study. Questionnaires and interviews posed some sensitive questions for the respondents and they felt uncomfortable supplying answers especially to a stranger. However, formal permission was granted by my case study organization. Hence, proper identification and clear details about me and the purpose of the research which was purely for academic Endeavour were given at the selected branches that I visited. The questions in the questionnaires were also biased, misleading or opinionated. Most importantly, privacy, right to withdrawal, anonymity.

Validity and Reliability Analysis: The strength and consistency for which research methodology is adjudged are made upon research validity as well as reliability (Morris \& Burkett, 2011). A thorough evaluation of validity and reliability for all secondary data involves an assessment of the data collection methods (Saunders et al., 2009). Confidentiality and right to free consent were spelt out to all the respondents. No gift or remuneration was given for participation; however, respondents' acceptance and contributions were duly acknowledged in the dissertation. Also, all collected data were digitally encrypted and locked in a cabinet and will be stored for no less than five years. It provides a good ground for data interpretation from instruments such as questionnaires, observer ratings and education tests used in research, administration and education (Cook \& Beckman, 2006). In a quantitative research Endeavour, there is a possibility of measurement being reliable but not valid; nevertheless, when a measurement is not reliable, then such can ever be valid (Thatcher, 2010; Twycross \& Shields, 2004). Similarly, according to Singh (2014), validity and reliability decrease the chances of inserting the bias of a researcher in the qualitative study but also increase its transparency.

This can be referred to as the degree to which an instrument assesses what it affirms to assess or measure (Blumberg et al., 2005). In other words, the validity of a research instrument evaluates the degree to which that instrument assesses what it is intended to assess (Robson, 2011). It is an essential prerequisite for all types of researches (Oliver, 2010). In quantitative research, it is the degree to which an instrument assesses what it affirms to assess (Thatcher, 2010) whereas in qualitative research it is when the researcher utilizes certain techniques to ascertain if the results of the study are accurate (Creswell, 2014). Validity entails the reliability of an instrument; however, there is a possibility of an instrument being reliable and yet not valid (Kimberlin \& Winterstein, 2008). Hence, the types of questions asked on the instrument are in harmony with the expected knowledge as well as in content validity. Furthermore, a pilot-test was carried out by the researcher with the use of questionnaires and the validity of the study was proven resulting from the pilottest that necessitated amendment of the study instrument to ascertain validity as well as reliability before the ultimate administration of the instrument.

The test showed a Cronbach Alpha Coefficient of 0.837 and 0.916 for all staff variables and all customer variables respectively, signifying reliability of the instrument. This is referred to as the degree to which a tool of evaluation yields results that are free from errors. In other words, the results of its measurement are stable and consistent with equivalent values (Blumberg et al., 2005). It evaluates precision, research repeatability, trustworthiness and consistency (Chakrabartty, 2013). It shows that the score recorded of an assessment truly replicates that assessment's score, implying fairness and without prejudice. Reliability refers to the repeatability, stability and consistency of outcomes in quantitative research which implies that if a researcher got a consistent outcome in same situations but in dissimilar circumstances, then the result of the researcher can be said to be reliable. Reliability coefficient ranges between 0 to 1 , where 1 indicates faultless reliability, with 0 indicating no reliability. The general rule for reliability is that for any $r>0.8$ is considered high and very good (Downing, 2004; Madan \& Kensinger, 2017). Furthermore, for this research, having obtained the secondary data from the audited financial statements of the bank which were in the public domain and indeed a reputable organization, the validity and reliability of the analysis outcome were assured.

Data Analysis Method: Since the present study is mainly quantitative, via the collection of a huge amount of information through the questionnaires administered, making use of inferential statistics summarized that huge amount of information in a tabular and graphical form. Hence, the inferential analysis was targeted at hypothesis testing. Excel and Statistical Package for Social Science (SPSS) were utilized for the analysis of the collected data. While excel helped in data grouping which also facilitated comparisons that were made, SPSS in a similar manner was very helpful in putting the data together which subsequently lead to the findings as well as the conclusions reached regarding the objectives of the study. This was the best for this research since 
it was mainly quantitative and involved interpretations of various numerical data collected to conclude upon testing the hypothesis. Multiple regression analysis options were used for the study because the analysis was done to determine the existence of any relationship between net interest margin (dependent variable) and the fees and commission income from various e-channels (independent variables).

\section{Results and Discussion of Findings}

Demographic Characteristics: Out of the 150 questionnaires distributed, 137 people responded, representing feedback of $91.3 \%$. As quipped by Cooper and Schindler (2011), a feedback rate of above 50\% is regarded as a good response for a survey. The summary of the result is as shown below:

Figure 1: Response Rate of the Questionnaire

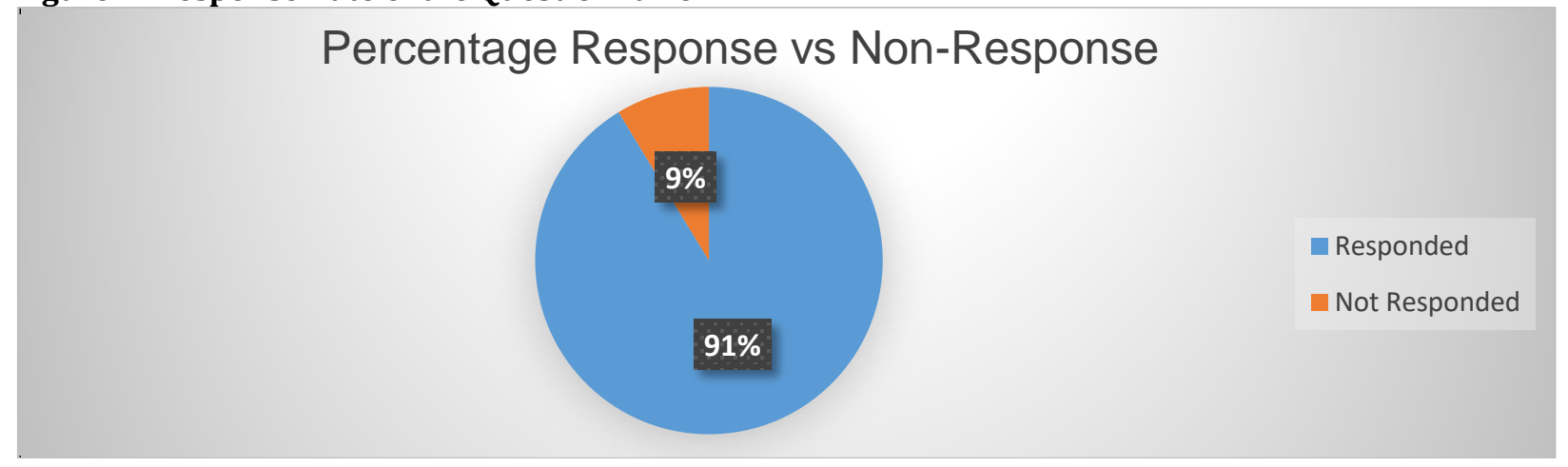

Table 1: Demographic Characteristics of Respondents Staff

\begin{tabular}{|c|c|c|c|}
\hline Variables & Items & Frequency & Percentage \\
\hline \multirow{3}{*}{ Gender } & Male & 34 & 49.3 \\
\hline & Female & 35 & 50.7 \\
\hline & Total & 69 & 100.0 \\
\hline \multirow{5}{*}{ Age } & $18-24$ & 11 & 15.9 \\
\hline & $25-35$ & 38 & 55.1 \\
\hline & $36-50$ & 19 & 27.5 \\
\hline & $51-60$ & 1 & 1.4 \\
\hline & Total & 69 & 100.0 \\
\hline \multirow{3}{*}{ Marital Status } & Single & 39 & 56.5 \\
\hline & Married & 30 & 43.5 \\
\hline & Total & 69 & 100.0 \\
\hline \multirow{6}{*}{$\begin{array}{r}\text { Educational } \\
\text { Status }\end{array}$} & Secondary & 4 & 5.8 \\
\hline & Diploma & 6 & 8.7 \\
\hline & $\begin{array}{l}\text { University } \\
\text { Degree }\end{array}$ & 46 & 66.7 \\
\hline & Master's Degree & 12 & 17.4 \\
\hline & Others & 1 & 1.4 \\
\hline & Total & 69 & 100.0 \\
\hline \multirow{3}{*}{ Occupation } & Employed & 68 & 98.6 \\
\hline & Other & 1 & 1.4 \\
\hline & Total & 69 & 100.0 \\
\hline
\end{tabular}

Source: Conducted Survey, 2018

Looking at the gender distribution, $49.3 \%$ were male, while $50.7 \%$ were female. This implied good participation by both genders though more female participated. Also, from the distribution of their age, $15.9 \%$ were within the age range of 18 -24years old, $55.1 \%$ were within the age range of $25-35 y$ years, $27.5 \%$ were within the age range of 36-50years, while $1.4 \%$ were within the age of 51-60years. Also, the marital status revealed that $56.5 \%$ were single, while $43.5 \%$ were married. Implying that most staff that participated was single. Furthermore, regarding their current educational status, 5.8\% had secondary school certificate, $8.7 \%$ had Diploma certificate, $66.7 \%$ had a university degree, $17.4 \%$ had master degree, while $1.4 \%$ had other degrees. Lastly, the distribution according to their occupation revealed that $98.6 \%$ were employed, while $1.4 \%$ chose other. 


\section{Testing of Hypothesis}

Testing of Hypothesis One: $\mathbf{H}_{1}$ : There is no contribution of e-banking channels to Access Bank's profitability.

Table 2: Regression Results for Hypothesis One

Model Summary

\begin{tabular}{llllll}
\hline Model & R & R Square & Adjusted R Square & Std. Error of the Estimate & Durbin-Watson \\
\hline 1 & $.999^{\mathrm{a}}$ & .998 & .991 & .0076092 & 2.712
\end{tabular}

a. Predictors: (Constant), MOBILE BANKING, CARDS, INTERNET BANKING, POS, ATM

b. Dependent Variable: Net Interest Margin

ANOVA $^{a}$

\begin{tabular}{lllllll}
\hline Model & & Sum of Squares & df & Mean Square & F & Sig. \\
\hline \multirow{3}{*}{1} & Regression & .046 & 5 & .009 & 159.737 & $.006^{\mathrm{b}}$ \\
& Residual & .000 & 2 & .000 & &
\end{tabular}

a. Dependent Variable: Net Interest Margin

b. Predictors: (Constant), MOBILE BANKING, CARDS, INTERNET BANKING, POS, ATM

\section{Coefficients $^{\mathbf{a}}$}

\begin{tabular}{|c|c|c|c|c|c|c|}
\hline \multirow{2}{*}{\multicolumn{2}{|c|}{$\overline{\text { Model }}$}} & \multicolumn{2}{|c|}{ Unstandardized Coefficients } & \multirow{2}{*}{$\begin{array}{l}\text { Standardized Coefficients } \\
\text { Beta }\end{array}$} & \multirow[t]{2}{*}{$\mathbf{t}$} & \multirow[t]{2}{*}{ Sig. } \\
\hline & & B & Std. Error & & & \\
\hline \multirow{6}{*}{1} & (Constant) & .565 & .011 & & 50.903 & .000 \\
\hline & POS & -1.126 & .198 & -1.290 & -5.700 & .029 \\
\hline & ATM & -.207 & .036 & -1.729 & -5.736 & .029 \\
\hline & CARDS & .003 & .001 & .267 & 5.245 & .034 \\
\hline & INTERNET BANKING & -.428 & .240 & -.311 & -1.784 & .216 \\
\hline & MOBILE BANKING & 1.803 & .258 & 2.362 & 6.976 & .020 \\
\hline
\end{tabular}

a. Dependent Variable: Net Interest Margin

Residuals Statistics ${ }^{\mathrm{a}}$

\begin{tabular}{llllll}
\hline & Minimum & Maximum & Mean & Std. Deviation & N \\
\hline Predicted Value & .272606 & .479105 & .373856 & .0812786 & 8 \\
Residual & -.0085790 & .0054835 & $0 \mathrm{E}-7$ & .0040673 & 8 \\
Std. Predicted Value & -1.246 & 1.295 & .000 & 1.000 & 8 \\
Std. Residual & -1.127 & .721 & .000 & .535 & 8
\end{tabular}

A. Dependent Variable: Net Interest Margin

Regression Analysis Results: From Table 2 above $\mathrm{R}^{2}$ gave .998 implying that E-Banking channels contributed about $99.8 \%$ of Access Bank's profitability. Adjusted $\mathrm{R}^{2}$ was .991, an indication that E-Banking channels contributed 99.1\% of Access Bank's profitability. Furthermore, the F-test result $=159.737$. The $t-$ statistics test results for POS, ATM, Cards, Internet Banking and Mobile Banking $=-5.700,-5.736,5.245,-1.784$ and 6.976 respectively were significant at $p=0.000<0.05$. The null hypothesis was therefore rejected with the conclusion that E-Banking channels contributed to Access Bank's profitability.

Testing of Hypothesis Two: $\mathbf{H}_{2}$ : E-banking does not have any influence on the retention and loyalty of bank's customers. 
Table 3: Regression Results for Hypothesis Two

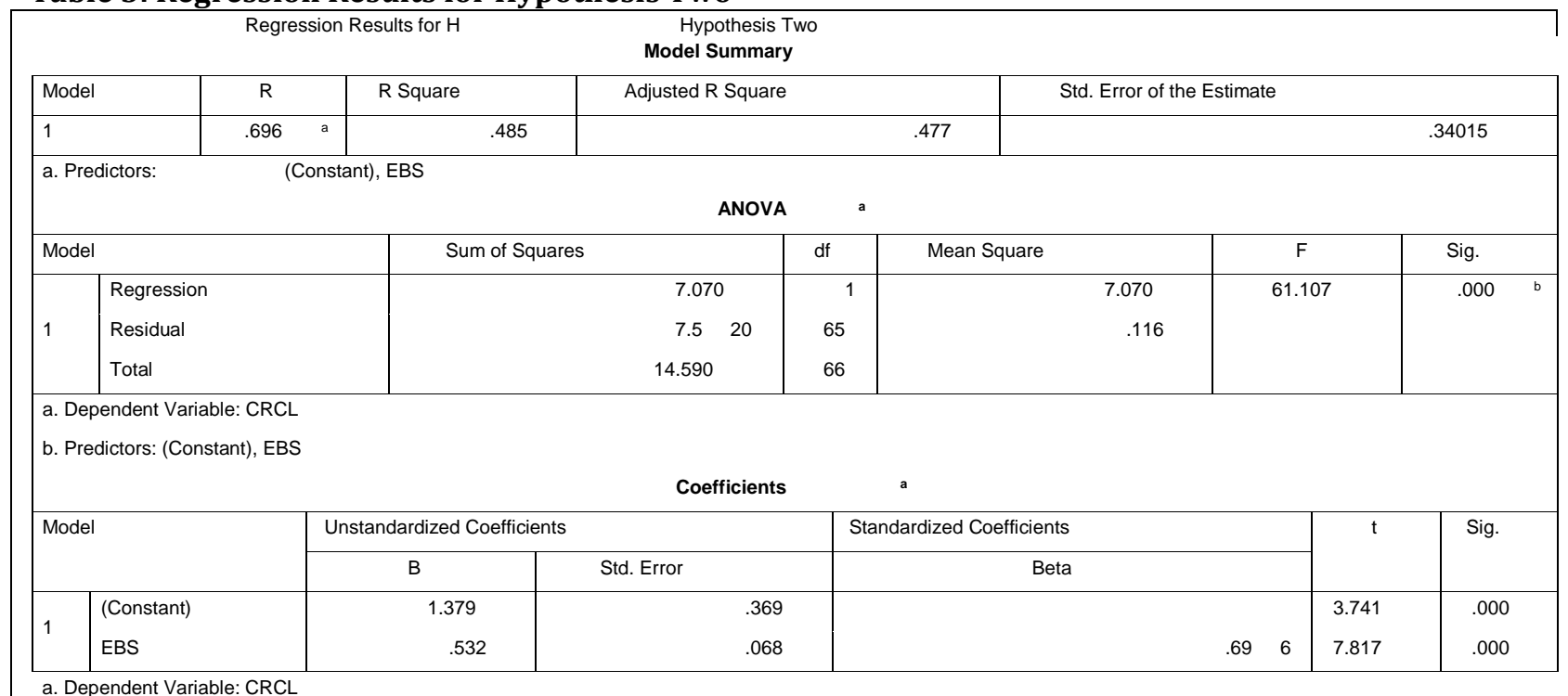

a. Dependent Variable: $\mathrm{CRCL}$

Regression Analysis Result: From Table 3 above, $\mathrm{R}^{2}$ gave .485 which meant that effective E-banking services (EBS) would contribute about $48.5 \%$ changes in customer retention and customer loyalty (CRCL). Adjusted $\mathrm{R}^{2}$ $=.477$, implying that E-banking services (EBS) would contribute about $47.7 \%$ changes in customer retention and customer loyalty (CRCL). Also, the F-test result was 61.107, also the t-statistics test result was positive at 7.817 and also significant at $p=0.000<0.05$. The null hypothesis was therefore rejected with the conclusion that E-banking services (EBS) influenced the retention and loyalty of bank's customers.

Testing of Hypothesis Three: $\mathbf{H}_{3}$ : The quality of service, security, reliability and efficiency does not influence the usage of e-banking services.

Table 4: Regression Results for Hypothesis Three

Variables Entered/Removed ${ }^{\mathrm{a}}$

Model Variables Entered

1 Efficiency, Service, Security, Reliability ${ }^{\mathrm{b}}$

Variables Removed

Method

a. Dependent Variable: EBS

b. All requested variables entered.

Model Summary

\begin{tabular}{llll}
\hline Model & $\mathrm{R}$ & R Square & Adjusted R Square
\end{tabular}

$\begin{array}{llll}.738^{\mathrm{a}} & .545 & .516\end{array}$

Std. Error of the Estimate

a. Predictors: (Constant), Efficiency, Service, Security, Reliability

ANOVA $^{a}$

\begin{tabular}{|c|c|c|c|c|c|}
\hline Model & Sum of Squares & df & Mean Square & $\mathbf{F}$ & Sig. \\
\hline Regression & 14.130 & 4 & 3.533 & 18.865 & $.000^{\mathrm{b}}$ \\
\hline Residual & 11.797 & 63 & .187 & & \\
\hline Total & 25.927 & 67 & & & \\
\hline
\end{tabular}

a. Dependent Variable: EBS

b. Predictors: (Constant), Efficiency, Service, Security, Reliability

Coefficients $^{\mathrm{a}}$

\begin{tabular}{|c|c|c|c|c|c|}
\hline \multirow[t]{2}{*}{ Model } & \multicolumn{2}{|c|}{ Unstandardized Coefficients } & \multirow{2}{*}{$\begin{array}{l}\text { Standardized Coefficients } \\
\text { Beta }\end{array}$} & \multirow[t]{2}{*}{$\mathbf{t}$} & \multirow[t]{2}{*}{ Sig. } \\
\hline & B & Std. Error & & & \\
\hline (Constant) & 1.352 & .531 & & 2.544 & .013 \\
\hline Service & .057 & .132 & .044 & .434 & .666 \\
\hline
\end{tabular}




$\begin{array}{llllll}\text { Security } & .242 & .098 & .275 & 2.457 & .017 \\ \text { Reliability } & .534 & .153 & .452 & 3.488 & .001 \\ \text { Efficiency } & .098 & .148 & .084 & .665 & .509\end{array}$

a. Dependent Variable: EBS

Regression Analysis Results: From Table 4 above, $\mathrm{R}^{2}$ gave .545 which implied that the quality of service, security, reliability and efficiency would influence $54.5 \%$ usage of E-banking services (EBS). Adjusted $\mathrm{R}^{2}$ gave .516, implying that the quality of service, security, reliability and efficiency will influence $51.6 \%$ usage of Ebanking services (EBS). In addition, the F-test result $=18.865$, and t-statistics test results for service, security, reliability and efficiency were all positive at $0.434,2.457,3.488$ and 0.665 respectively and significant at $p=$ $0.000<0.05$. The null hypothesis was therefore rejected with the conclusion that the quality of service, security, reliability and efficiency influenced e-banking services usage.

Discussion of Findings: There was a strong agreement from the majority of the respondents' staff and customers that electronic banking method being used by Access Bank offers quick service and ease of transfer of funds electronically from one account to the other. Also, the electronic banking services of the bank were safe and secure and that the e-banking services were available 24hours a day. That using electronic banking services was time-saving and that it was cheaper to do transactions through electronic banking channels. These submissions were in tandem with the findings of Mawutor (2014), where the respondents agreed that benefits of e-banking were far more than its inherent problems and that it offered quicker means of rendering financial services than the traditional means. Also, the staffs were of the view that there were lots of benefits in using the bank's electronic channels.

Also, the electronic banking applications were user friendly and that Access bank e-banking service can be accessible in every part of Nigeria. These were also in agreement with Ovidiu et al. (2015) in their study on performance effect of e-banking on Romanian banking sector where they concluded that internet brought a complete shift in paradigm in the structure of financial systems and services in meeting customers' aspirations and needs with incredible benefits. The result from the secondary data extracted from the organization as well as the audited financial reports of the bank from 2010 to 2017 showed that E-banking contributed about $25 \%$ of the total profit after tax of Access Bank Nigeria Plc. It also revealed that cards had the highest contribution of about 77\% of profitability of E-banking channels of Access Bank within the eight years, followed by ATM, Mobile. Corporate Payments, POS and internet banking which contributed 16\%, 2\%, $1.6 \%, 1.5 \%$ and $1.2 \%$ respectively. After running the test of the hypotheses using inferential statistics, it revealed that E-Banking channels contributed to Access Bank's profitability.

This finding supported the views of Mawutor, (2014) who investigated the profitability impact of e-Banking in Ghanaian Banks and came to the conclusion that there has been visible progress since the dawn of ebanking, with the resultant growth in customer's patronage as a result of services that are efficient and effectives. In the second hypothesis, it showed that the services of e-banking influenced the bank's customer retention as well as loyalty. This was also in line with Kadzo and Wafula (2015) who concluded that internet banking adoption leads to a reduction in transaction cost and attraction of more customers. Nevertheless, there was a negative as well as the substantial impact on ROA of banks from commission and fees from internet banking. Lastly, in the third hypothesis, the study concluded that the quality of service, security, reliability and efficiency influenced the e-banking services usage. This finding conformed with the views of Njogu (2014) where he examined the profitability impact of e-banking on Kenyan commercial banks and discovered that for Kenyan commercial banks that the bank's size determined their financial result or performance and also that the relationship that existed between financial performance and e-banking is strong and positive.

\section{Conclusion, Recommendations and Policy Implications}

This research examined the effect of electronic banking on profitability in the Nigerian banking sector, with particular reference to Access Bank Plc. The study specifically looked into the impact of e-channels on the profit of Access Bank; the challenges experienced by the Bank in its product offering of electronic banking, as well as the prospects of effectively applying those electronic channels to its customers to satisfy their banking 
needs. Competition is indeed stiff in the Nigerian banking industry because every player is looking for ways to out-do the other to maximize profit and render good returns to its shareholders. Access Bank as one of the Systemically Important Banks in Nigeria Banking industry has had their fair share of e-banking challenges as stated earlier just like the other players in the industry. This is because the industry is a choked marketplace that consists of various financial firms amongst others.

All of which are playing actively in the industry and virtually competing for who will have the lion share of the market. The study also involved the review of some literature that was related to the research as well as some relevant theories to underscore the objectives of the study. These theories include; Social construction of technology theory (SCOT), the Theory of Reasonable Action (TRA) and Technology Acceptance Model (TAM). On the other hand, chapter three of this study drew attention to the research methods, research design, population and sampling techniques adopted as well as the method of data analysis, while chapter four gave an insight into the appropriate quantitative analysis used for the study. The quantitative study made use of inferential statistics and applied multiple linear regression analysis to conclude.

Conclusion: Based on the empirical findings of several kinds of literature reviewed, it was established that there had been a tremendous improvement in the profitability of banks since the dawn of electronic banking. There was also diverse evidence regarding the effect of electronic banking on the results of banks. Hence, the need for scholars, regulators and bankers themselves to comprehend exactly the way banks' performances is affected by e-banking. This is very imperative and expedient. This study sought to answer three questions which were; what the contribution of e-banking channels was to the profit of Access Bank; whether e-banking had any influence on the retention and loyalty of bank's customers; and if there were improvements in the quality of service, security, reliability and efficiency due to the usage of the services of electronic banking.

Recommendations: About the findings as well as the conclusions of this research and for the enhancement of the banks' capabilities, this study recommends that the Nigerian banking industry should invest more in Card products followed by ATM amongst other electronic channels; as they generate more revenues for the bank. Also, because only $25 \%$ of the profit from the study came from electronic banking, the study recommends further development of other channels (Mobile, Corporate Payments, POS and internet banking) to further enhance their contribution to the bank's profitability. A well-articulated strategy to diversify income is also recommended. Regarding ATM, Nigerian banks should consider the reduction of N65 charge after the third withdrawal from the ATM of another bank and also increase daily withdrawal limit to encourage more usage and income enhancement. Furthermore, banks should ensure that their ATM outlets are strategically located and properly maintained such that it will be easily accessible to the retail customers. Customers are the reason why banks are in business, so this study further recommends that Nigerian banks should create a business strategy that is customer-centric by being continuously innovative in identifying the needs of their customers and improving on their products offering. The study concluded that Cards is one of the electronic banking channels play a significant role amongst other channels and immediately followed by ATM. Also based on the research questions and hypothesis one, it was concluded that E-Banking channels contributed to Access Bank's profitability. Also, the second hypothesis concluded that E-banking services (EBS) influenced the retention and loyalty of bank's customers.

Finally, concerning hypothesis three, it was concluded that the quality of service, security reliability and efficiency influenced usage of e-banking services while developing new ones, to retain and keep the loyalty of their existing customers while attracting new ones. The aim of the banks should be to make electronic transactions less risky, tightly secured and convenient for customers. Nigeria is a multi-cultural society with vast ethnic diversity and still very low financial inclusion. Also, despite the campaign for a cashless society, cash related transactions still account for the majority of transactions that take place in the country. Hence, this study recommends that Nigerian banks in conjunction with the Central Bank of Nigeria should embark on a serious campaign to educate and promote the embrace and usage of e-banking for day to day transactions particularly in the grassroots. The education, awareness, jingles and the entire campaign should be done in the native language of the people to reach many that are unbanked and under-banked in our society. With the development and expansion of e-banking in the Nigerian society, banks will be faced with service, reliability, security and efficiency issues. So, this study recommends that banks should fortify their security systems of the network to detect easily. It is also recommended that adequate training and motivation should be given to 
the staffs that are charged with these responsibilities. Daily inspection, as well as the daily report of incidents, is also recommended to forestall colossal error. Since one of the oversight functions of the regulators is to engender trust, protect the right of consumers as well as to boost the confidence of the public in the banking sector, this study further recommends that the Central Bank of Nigeria should come up with policies that will fortify its supervision on the risks of e-banking to achieve their financial inclusion vision.

However, there are a few limitations to this study. Both secondary, as well as primary data were used for this research and indeed, it was a bit difficult to get a timely response from the staff of the bank used as a case study. This was because most of them were apprehensive on the grounds of not divulging any information about the bank that could be traced to them and probably jeopardizing their career. In the same vein, it was very difficult to get the exact amount contributed by each of the e-channels (POS, ATM, Cards, Internet, Corporate Payments and Mobile) to the total fees and commission. Which could only be seen as a lump sum in the financial statements particularly when it involved more than two years as it was considered highly confidential? Most of the studies from various literature reviewed, focused on factors that affect the adoption of e-banking (Ashtiani \& Iranmanesh, 2012), others focused on the relationship between demographic characteristics and electronic banking (Worku et al., 2016) while some tried to ascertain customers commitment and satisfaction through the use of internet banking (Singh \& Kour, 2011; Ma, 2012). This research identified a gap by assessing the impact of electronic banking on profitability in the Nigerian banking industry with the particular objective of seeking to find the contribution of each of the channels to profitability to isolate the channels that contribute more to bank's profit. The research concluded that cards being one of the channels play a significant role amongst other channels and immediately followed by ATM in terms of contribution to profitability while internet banking contributed the least to the profitability. This research is therefore recommending further study to be carried out on the same topic, but with at least other three Systemically Important Banks (SIB) in Nigeria to establish a generalization of this research outcome.

Acknowledgement: This paper is an extracts from a Master of Business Administration thesis at the University of Roehampton, London. Prof. Olawumi .D. Awolusi was the supervisor of the study.

\section{References}

Abaenewe, Z. C., Ogbulu, O. M. \& Ndugbu, M. O. (2013). Electronic Banking and Bank Performance in Nigeria. West African Journal of Industrial and Academic Research, 6(1), 171-187.

Ajzen, I. (1991). The theory of planned behavior. Organizational Behavior and Human Decision Processes, $50(2), 179-211$.

Angelakopoulos, G. \& Mihiotis, A. (2011). E-banking: challenges and opportunities in the Greek banking sector. Electronic Commerce Research, 11(3), 297-319.

Ashtiani, P. G. \& Iranmanesh, A. (2012). New approach to the study of factors affecting the adoption of electronic banking services with an emphasis on the role of positive word of mouth. African Journal of Business Management, 6(11), 4328-4335.

Awolusi, 0. D. (2012). Effectiveness of total quality management on business performance in Nigerian manufacturing firms: an empirical analysis, International Journal of Enterprise Network Management, $5(3), 254-271$.

Awolusi, O. D. \& Onigbinde, I. O. (2013). Enterprise Resource Planning and organizational performance in Nigerian manufacturing firms: an empirical analysis. Global Journal of Commerce and Management Perspective, 2(4), 12-23.

Awolusi, O. D. \& Akinruwa, T. E. (2014). Cultural Combination and International Acquisition Performance of Multinational Corporations in Nigeria. Global Journal of Commerce and Management Perspective, 3(1), $1-14$.

Basel Committee on Banking Supervision. (1998). Risk Management for Electronic Banking and Electronic Money Activities. Journal of Small Business Management, 4(2), 51-840.

Basel Committee on Banking Supervision. (2003). Risk Management Principles for Electronic Banking. Bank for International Settlement. Journal of Business, 18(5), 93-147.

Berenson, M. (2006). Basic business statistics: concepts and applications (12 th Ed.) London: Pearson. 
Blazi, C. \& Awolusi, O. D. (2020). Employee Engagement in Multinational Diverse Organization in Difficult Terrain: A Study of Non-Family Station Organization, Information Management and Business Review, 12(1), 45-62.

Blumberg, B., Cooper, D. R. \& Schindler, P. S. (2005). Business Research Methods. Berkshire: McGraw-Hill Education.

Chakrabartty, S. N. (2013). Best Split-Half and Maximum Reliability. IOSR Journal of Research \& Method in Education, 3(1), 1-8.

Cheng, T. C., Lam, Y. C. \& Yeung, C. L. (2006). Adoption of internet banking: An empirical study in Hong Kong. Decision Support Systems, 42(3), 1558-1572.

Cohen, L., Manion, L. \& Morrison, K. (2007). Research methods in education (6 $6^{\text {th }}$ Ed.) New York, USA: Routledge.

Collins, J. (2001). Level 5 leadership: The Triumph of Humility and Fierce Resolve. Harvard Business Review, 83(7-8), 136-146.

Cook, D. A. \& Beckman, T. J. (2006). Current Concepts in Validity and Reliability for Psychometric Instruments: Theory and Application. The American Journal of Medicine, 119(1), 166.e7-166.e16.

Coombs, C. H. (1987). The structure of conflict. American Psychologist, 42(4), 355-363.

Cooper, D. R. \& Schindler, P. S. (2011). Business Research Methods (9 ${ }^{\text {th }}$ Ed.) McGraw Hill.

Creswell, R. (2014). Research Design: Qualitative, Quantitative, and Mixed Methods Approaches. USA: SAGE Publications.

Crotty, M. (1998). The foundations of social research. London: Sage.

Davis, F. D., Bogozzi, R. P., \& Warshaw, P. R. (1989). User acceptance of computer technology: A comparison of two theoretical models. Management of Science, 35(1), 982-1003.

Davis, F. D. (1989). Perceived usefulness, perceived ease of use, and user acceptance of information technology. MIS Quarterly, 13(3), 319-340.

Devi, J. T., Pudaruth, S. \& Ramdin, P. (2012). Factors influencing the adoption of internet banking: a case study of commercial banks in Mauritius. World Journal of Science, Technology and Sustainable Development. 9(3), 204-234.

Downing, S. M. (2004). Reliability: On the Reproducibility of Assessment Data. Med Education, 38(1), 1006-12.

Easterby-Smith, M., Thorpe, R. \& Jackson, P. (2012). Management Research (4th Ed.). London: SAGE Publications.

Eccles, R. G. \& Serafeim, G. (2013). The Performance Frontier: Innovating for a Sustainable Strategy. Harvard Business Review, 1-10.

Farris, P. W., Bendle, N. T., Pfeifer, P. E. \& Reibstein, D. J. (2010). Marketing Metrics: The Definitive Guide to Measuring Marketing Performance ( $2^{\text {nd }}$ ed.), Pearson Education, Upper Saddle River, New Jersey.

Fishbein, M. \& 0Ajzen, I. (1975). Belief, attitude, intention, and behavior: An introduction to theory and research. Reading, Mass; Don Mills, Ontario: Addison-Wesley Pub. Co.

Grix, J. (2004). The Foundations of Research. London: Palgrave Macmillan.

Harihara, S. R. \& Pavithra, V. (2012). A Study on Customer Perception and Awareness in the Usage of Internet Banking. International Conference on Strategic trends on Innovations and Creativity on Management Practices. Available at: http://papers.ssrn.com/sol3/papers.cfm?abstract_id=2187245 (Accessed: 07/04/18).

Hernando, I. \& Nieto, M. (2006). Is the Internet Delivery Channel Changing Banks' Performance? The Case of Spanish Banks. Banco de Espana Research Paper No. WP-0624.

Hong, S. J., Thong, J. Y. L. \& Tam, K. Y. (2006). Understanding Continued Information Technology Usage Behavior: A Comparison of Three Models in the Context of Mobile Internet. Decision Support Systems, 42(3), 1819-1834.

Jayawardhena, C. \& Foley, P. (2000). Changes in the banking sector -The case of Internet banking in the UK. Internet Research, 10(1), 19-30.

Johnson, S. (2014). Advantages and Disadvantages of Positivism. Available at: http://www.ehow.com/info_12088541_advantages-disadvantages-positivism.html (Accessed: 07/05/18).

Kadzo, S. \& Wafula, M. K. (2015). Effects of Internet banking on the Financial Performance of Commercial Banks in Kenya (A Case of Kenya Commercial Bank). International Journal of Scientific and Research Publications, 5(5), 9-20. 
Kaur, R. (2013). The Impact of Electronic Banking on Banking Transactions: A Cost-Benefit Analysis. IUP Journal of Bank Management, 12(2), 62-71.

Kimberlin, C. L. \& Winterstein, A. G. (2008). Validity and Reliability of Measurement Instruments Used in Research. American Journal of Health-System Pharmacists, 65(1), 2276- 2284.

Kricks, T. (2009). CARTA \& Caribbean Group of Banking Supervisors. It Workshop for Regional Bank Examiners. International Journal of Small Business Management, 4(10), 51-84.

Kolodinsky, J. M. \& Hogarth, J. M. (2004). The adoption of electronic banking technologies by US consumers. The International Journal of Bank Marketing, 22(4), 238-259.

Lai, P. C. (2016). Design and Security impact on consumers' intention to use single platform E-payment. Interdisciplinary Information Sciences, 22(1), 111-122.

LeBeouf, M. (1987). How to Win Customers and Keep them for Life. Berkley Publishing Group: New York, USA.

Lee, G. \& Lin, H. (2005). Customer's perception of e-service quality in online shopping. International Journal of Retail and Distribution Management, 33(2), 316-322.

Liu, Y., Li, H. \& Carlsson, C. (2010). Factors driving the adoption of m. learning: An empirical study. Computers and Education, 55(3), 1211 - 1219.

Ma, Z. (2012). Factors affecting the customer satisfaction of internet banking: An Empirical study in China. Journal of Convergence Information Technology, 7(3), 101-109.

Madan, C. R. \& Kensinger, E. A. (2017). Test-Retest Reliability of Brain Morphology Estimates. Brain Informatics, 4(1), 107-121.

Matira, K. M. \& Awolusi, O. D. (2020). Leaders and Managers Styles towards Employee Centricity: A Study of Hospitality Industry in the United Arab Emirates, Information Management and Business Review, 12(1), 1-21.

Mawutor, J. K. M. (2014). Impact of E-Banking on the Profitability of Banks in Ghana. Research Journal of Finance and Accounting, 5(22), 53-63.

Morris, E. \& Burkett, K. (2011). Mixed Methodologies: A New Research Paradigm or Enhanced Quantitative Paradigm. Online Journal of Cultural Competence in Nursing and Healthcare, 1(1), 27-36.

Mukonga, L. M. \& Awolusi, O. D. (2019). Strategic Leadership in the Post-Conflict States: A Study of the Democratic Republic of Congo (DRC), Journal of Social and Development Sciences, 10(4), 36-51.

Ngai, L. W. T., Poon, J. K. L. \& Chan, Y. H. C. (2007). Empirical examination of the adoption of WebCT using TAM. Computers and Education, 48(2), 250 - 267.

Njogu, J. N. (2014). The effect of Electronic Banking on Profitability of Commercials in Kenya. A Research Project Submitted in Partial Fulfillment of The Requirements for The Award of The Degree of Master of Science in Finance, School of Business, University of Nairobi. Available at: (Accessed: 05/05/18).

Olatunji, O. O. \& Awolusi, O. D. (2019). Performance Evaluation and Improvement among Salesmen in the Nigerian Fast Moving Consumer Goods Sector, Journal of Social and Development Sciences, 10(4), 1229.

Oliver, V. (2010). 301 Smart Answers to Tough Business Etiquette Questions. Skyhorse Publishing: New York, USA.

Onikoyi, I. A., Babafemi, E. A. \& Awolusi, O. D. (2013). Biblical and Societal appraisal of divorce amongst Christians. Babcock Journal of Management and Social Sciences, 2(1), 72-90.

Ovidiu, S. \& Alina, S. (2015). The impact of internet banking on the performance of Romanian banks: DEA and PCA approach.

Pitt, M. \& Koufopoulos, D. N. (2012). Essentials of Strategic Management. London: Sage

Rad, H. S., Rasoulian, A., Mirzaei, M. \& Sharifipour, A. (2017). Electronic Banking; a New Strategy to Create Customers' Loyalty to Investment and Its Impact on Economic Initiatives. International Journal of Management, Accounting and Economics, 4(4), 431-442.

Rauf, H. (2014). Trends in China's E-commerce Market. Available at: http://www.chinabriefing.com/news/2014/06/04/trends-chinas-e-commerce-market.html (Accessed: 23/09/18).

Reeves, M., Love, C. \& Tillmanns, P. (2012). Your Strategy Needs a Strategy. Harvard Business Review, 23(2), 234-245.

Robson, C. (2011). Real World Research: A Resource for Users of Social Research Methods in Applied Settings, ( $2^{\text {nd }}$ Ed.). Sussex, A. John Wiley and Sons Ltd.

Salawu, R. O. \& Salawu, M. K. (2007). The Emergence of Internet Banking in Nigeria: An Appraisal. Information Technology Journal, 6(4), 490-496. 
Salehi, M. \& Alipour, M. (2010). E-banking in an emerging economy: Empirical evidence of Iran. International Journal of Economics and Finance, 2(1), 201-209.

Saunders, M., Lewis, P. \& Thornhill, A. (2009). Research Methods for Business Students, (5 ${ }^{\text {th }}$ Ed.). Harlow, Pearson Education.

Shekharan, U. \& Bougie, R. (2010). Research Methods for Business: A Skill Building Approach (5 ${ }^{\text {th }}$ Ed.). New Delhi: John Wiley.

Simpson, J. (2002). The Impact of the Internet in Banking: Observations and Evidence from Developed and Emerging Markets. International Journal of Telematics and Informatics, 19(1), 315-330.

Singh, A. S. (2014). Conducting Case Study Research in Non-Profit Organizations. Qualitative Market Research: An International Journal, 17(1), 77-84.

Singh, J. \& Kour, G. (2011). Customer satisfaction and universal banks: An empirical study. International Journal of Commerce and Management, 21(4), 327-348.

Shih, Y. Y. \& Fang, K. (2004). The use of a Decomposed Theory of Planned Behavior to study Internet banking in Taiwan. Internet Research, 14(3), 213-223.

Sumra, S. H., Manzoor, M. K., Sumra, H. H. \& Abbas, M. (2011). The Impact of E-Banking on the profitability of Banks: A Study of Pakistani Banks. Journal of Public Administration and Governance, 23(2), 23-34.

Thatcher, R. (2010) Validity and Reliability of Quantitative Electroencephalography. Journal of Neurotherapy, $14(1), 122-152$.

Twycross, A. \& Shields, L. (2004). Validity and Reliability-What are it All About? Part 2: Reliability in Quantitative Studies. Pediatric Nursing, 16(10), 23-36.

Wang, D. H., Claire, L., Kenneth, B. Y. \& Randell, B. (2009). To trust or not to trust: The consumer's dilemma with e-banking. Journal of Internet Business, 6(2), 1-27.

Worku, G., Tilahun, A. I. \& Tafa, M. A. (2016). The Impact of Electronic Banking on Customers' Satisfaction in Ethiopian Banking Industry (The Case of Customers of Dashen and Wogagen Banks in Gondar City). Journal of Business \& Financial Affairs, 5(2), 1-18.

Yang, J., Cheng, L. \& Luo, X. (2009). A comparative study on e-banking services between China and USA. International Journal of Electronic Finance, 3(3), 235-252.

Yang, S., Li, Z., Ma, Y. \& Chen, X. (2018). Does Electronic Banking Really Improve Bank Performance? Evidence in China. International Journal of Economics and Finance, 10(2), 82-94. 